\title{
CONCEPTUAL MODEL OF THE SYSTEM OF MODERN COMMUNICATIONS IN PUBLIC GOVERNANCE
}

\author{
Marian Tokar ${ }^{1}$, Nataliia Varenia $^{2}$, Inna Kulchii ${ }^{3}$ \\ ${ }^{I}$ Ph.D. (Historical Sciences), Professor, Director, Augustyn Voloshin's Carpathian University, Research \\ Institute of State Formation and Public Administration, Uzhhorod, Ukraine, e-mail: \\ carpatia.doslid@gmail.com,ORCID: https://orcid.org/0000-0001-8426-4481 \\ ${ }^{2}$ Ph.D. (Law), Applicant, National Academy of Security Service of Ukraine, Kyiv, Ukraine, e-mail: \\ annajasko@ rambler.ru,ORCID: https://orcid.org/0000-0002-2797-197X \\ ${ }^{3}$ Ph.D. (Public Administration), Associate Professor Department of Public Administration and Law, \\ Department of Public Administration and Law, National University «Yuri Kondratyuk Poltava Polytechnic», \\ Poltava, Ukraine, e-mail: nafusail@gmail.com, ORCID: https://orcid.org/0000-0002-0063-6493
}

\begin{abstract}
The academic paper considers the issues of substantiation of the application of mechanisms for the implementation of communications in the sphere of public administration and the development of practical recommendations to the authorities to improve their work in this area. The process of forming a communicative interaction mechanism as a consistent application of legal and organizational measures is based on fundamental principles, purposefulness and application of certain management methods aimed at meeting the information environment and communication needs of the community, the organization of effective functioning of the state. The possibility of improving the processes of formation of public (social) opinion has been considered, using the definition of its main components, which should be taken into account during the implementation of mechanisms of communication. The existing methods of using voluntary mutual communication between community members have been considered, which should be used during the operation of communication mechanisms in the sphere of public administration, namely: mailboxes, Internet access, using of frequently asked questions (FAQ). It has been recommended to pay attention to the following directions: strengthening openness and transparency of work; development and use of the latest mechanisms in interaction with community members and their public organizations; application of the newest methods of studying social and economic and political processes in work, the account and monitoring of opinions of various groups and layers of civil society; strengthening the responsibility of the authorities to the community through the introduction of various types of intersectoral social partnership in solving important problems for the community; achieving the required level of mutual trust, social understanding, integration and consolidation.
\end{abstract}

Keywords: state administration (governance), communication, communication (communicative) interaction, public (social) management, communication behavior, act of communication, communication process, communication partnership.

JEL Classification: H70, M10, M14, M15

Formulas: 0; fig .: 1; tab .: 0; ref.: 15

Introduction. Application of various methods and forms of civil communication, free access of community members to information at all stages of decision-making and functioning of central and local authorities, participation of civil society institutions in the work of expert, advisory, consultative public councils on the expression and protection of civil rights and freedoms, public control, direct electronic access to public services, etc. are important factors in the implementation of democratic principles of state governance. After all, we are talking about a conscious focus on new values of individuals and groups, their specific participation in the democratic organization of life of the state and society. The main issue in this context is that the rational consensus of civil society and the state is the basis of 
universal status and a strategic resource for the development of a democratic society. Thus, communication in the society, taking into account the components of democratization of state governance by bodies, acquires special significance not only for state authorities, but also for civil society institutions.

Literature review. The concept of "communication" is very often used in modern interpretation. Scientists have paid considerable attention to the study of this category, namely: Cooley C. (study of the theory of small groups in the society), Lazarsfeld P., Laswell G., McLuhan M. (study of the influence of electronic communication on the formation of the human and the society, in particular, the concept of global society), Noelle-Neumann E., Park R. (study of behavior in urban and other spheres of the society), Khabermas $\mathrm{Yu}$. et al. (study of communicative interactions of the society as a basis in which rational arguments are put forward and rejected; study of communicative action, discourse and rationality); they have considered communicativeness as a system in which the process of mutual action takes place and the types of mutual communication are used, which make it possible to reproduce, transmit and receive information of various kinds [1]. A review of the scientific opinions of scholars shows that, despite the fact that the category of "communication" is the subject of research and use of a fairly large range of natural sciences and humanities, the issues concerning the functional specifics of communication and the democratic resource of systemic influence on the effectiveness of the interaction of state authorities and the public have not yet found a comprehensive solution in the science of state institutions' management $[2,6]$. Furthermore, the problem of the impact of civil communication on the formation and further development of democratic governance in Ukraine, taking into account the experience and requirements of European standards of democratic principles of development, has not become a special object of research yet.

Numerous different approaches, practical solutions and technical methods of accomplishment are used in the implementation of management measures, which make it possible to streamline, unilaterally direct and more effectively ensure the organization of the tasks facing the stages, functional actions, operations and procedures required to identify and make an effective decision [9]. Their accumulation constitutes tools and techniques of management, justifying the chosen methods of carrying out management activities and are used in determining, setting and achieving the expected goal. There are three basic models of the decisionmaking process in the practice of management theory, namely: the classical model; behavioral model and irrational model $[1,12]$.

The use of modern information technologies and technological results of development of mass media sphere in the field of information terrorism is an interesting, still insufficiently researched direction of application of communicative information systems in the public information environment. Using the mass media tools, it is possible to gain powerful levers of influence on consciousness, which through manipulative technologies, neurolinguistic programming methods and other means of information influence become important enough to cause destabilization in a society, inflame fears and panic and, as a result, get a real opportunity to impose 
their demands. However, this kind of information is openly lopsided and achieves its goal not due to the quality of manipulative influence, but due to its volume.

If the objects of such influence successfully achieve the necessary emotional and psychological state, it becomes quite possible to use artificially created "public opinion" to put pressure on the government in order to force the latter to make inadequate management decisions. This, in turn, directly affects the security situation, the state of the economy and the social sphere.

Aims. The purpose of the study was a theoretical and methodological consideration of civil communications in terms of strategic resources for further democratization of state governance and specification of proposals for the application of the results obtained in the functioning of public administration. Investigation of the peculiarities of the state governance's influence on the process of public administration provides the widespread use and application of various democratic forms and methods of government, namely: free access of citizens to information in the process of making managerial decisions and actions, participation of civil society institutions in the work of expert, advisory, consultative public councils on the protection of the rights and freedoms of citizens; civil control; direct electronic receipt of public services, etc.

Methods. Methods of logical comparison, systematization and generalization were used, which made it possible to achieve the research goal. The research methods used in the process of writing the academic paper involved the application of general scientific and empirical techniques of economics, based on a systematic approach. Methods of critical analysis of published research results in the field of construction of modern communications in state administration in modern systems of public authorities have been also used; logical comparison of the results obtained has been carried out, as well as systematization and generalization, which allowed to achieve the goal of the study. In addition, general research methods such as generalization and comparison have been used in the working process.

Results. Analysis of numerous conceptual definitions of the term "communication" in the vast majority of cases centers around considering them according to various features. Basically, there are three conceptual-typical groups existing in scientific concepts, namely [2]: communication as a connection between objects; communication as an analogue of communication; communication as an analogue of influence. The main features, characterizing an effective communication process are as follows: the presence of a goal aimed at obtaining the desired result; continuity, that is, the permanence of the communication process; communication always objectively possesses the properties of relativity - talking about ideal communication relations is possible only from the standpoint of theory; communication is based on certain normative and cultural codes; in communication, the so-called feedback is important - the presence (or absence) of a reaction to the message [3].

The real conditions in which the world exists, provided with innovative channels of public communication, lead to changes in the general basic principles and principles of organizing life, activity and coexistence in the society, to 
transformational changes in the behavior of the individual. This is due to the introduction, development and use of new modern technologies and communication practices through the acquisition of a new, uninvestigated environment of public communication, which has the features and means of carrying out specific activities there. Currently, powerful communication processes occur mainly in the electronic network Internet. This, in turn, requires the individual user to study "the latest" systems of knowledge, norms, values and patterns of behavior, as well as the ability to naturally and effortlessly implement them in today's communicative environment.

This environment, surrounding the individual user, needs to replenish the basic information arrays of general public importance and social databases, all components of the structure of the environment with updated resources. Such communications act as tools for meeting the information needs of the entire system of public use of local information resources and resources of global information support of this space, providing conditions for proper access to information to all categories of users among the community. At the same time, providing opportunities for independent creation of information arrays, self-expression in the information environment of the field of activity for all citizens during the entire process of establishing democratic foundations in the society [4, c. 57].

The functioning of the mechanism of interaction of communications in the field of public administration should be analyzed as a consistent implementation of a systemic complex of legal actions for organizing activities, based on generally accepted foundations and principles, with the application of target orientation and the use of specific management methods and techniques focused on meeting the information requirements and needs of the population in communications and, as a result, the organization of government authorities (Figure 1). The purpose of this interaction is to meet the information requirements and communication needs of the subjects of communication interaction in the sphere of public administration and management.

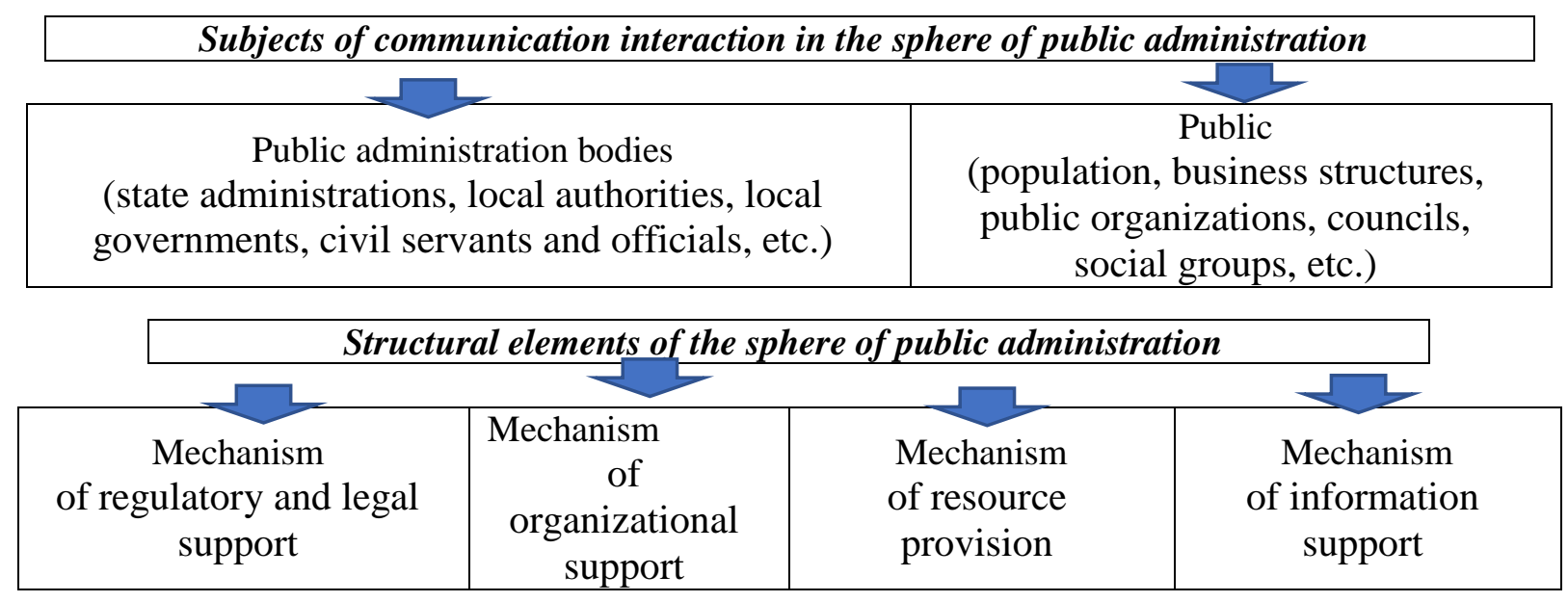

Figure 1. Generalized structural model of communication interaction in the sphere of public administration 
The principles of introduction of communication interaction in the sphere of public administration are as follows: guarantee of the right to receive information; truthfulness, ensuring access to sources of information and its free dissemination; objectivity, information reliability; accuracy and completeness; legislative confirmation of the legality of receipt, use, transmission and storage. The result should be an improvement in the efficiency of state authorities in the sphere of public administration by optimizing communication between the state and the public.

Intrinsically, regardless of the peculiarities of power in a particular chosen state, the opinion of the vast majority of citizens - members of the society, and equally regardless of the identified expression of the collective's opinion, there is a conscious obligation of the authorities to take this opinion into account, as the authorities will not be able to govern the public. Forasmuch as the power is a process mechanism of rationally organized management of processes in the society, aimed at meeting the needs, requirements and interests of the majority in civil society, it is obvious that government institutions are designed to fully adequately and timely respond to innovation, taking into account in its own management strategy the latest trends in the system of expectations and values reflected in the minds of the community and, of course, in the behavior of community members. Within the conditions when the real influence of community opinion on the policy of government institutions is recognized, a natural, legitimate issue arises about its possible using to achieve the political and ideological goals set by the government.

Competent and concerned use of communication interaction gives the chance not only to keep accurately directed influence on management of the leading main subjects over the public. This is often an additional opportunity to consciously choose the most acceptable mechanisms and ways within a long political process and its transformation. It, in turn, is connected to a greater extent with the formation of stable and active institutions of civil democratic society and the law-governed state. However, the positive completion of this process is impossible without a constant constructive dialogue between the society and the government.

Subjects (carriers) of public (social) opinion, in general, are steady in terms of stability of the community of citizens, which is characterized by a certain opinion, whose interests it reflects, from the position of which it evaluates a phenomenon of social reality, determines the attitude to it. At the same time, the manifestations of public opinion can be inherent in any association of people, organizations, the media and even individuals.

Therefore, in our opinion, it is of interest to study the process of formation of public (social) opinion through the introduction of mechanisms of communication in the sphere of public administration.

"The Code of Best Practices for Public Participation in the Decision-Making Process" declared by the Council of Europe states that public authorities should be characterized by absolute transparency at absolutely every stage of development and implementation of policy decisions together with public organizational structures $[5$, 6]. It is this approach today can guarantee the establishment of constructive relations 
between state authorities and the public in such basic forms of communicative interaction as [7, p. 24]:

- information (open access to objective and timely information);

- real-time consultations in order to identify public opinion and develop appropriate proposals;

- dialogue through hearings, community forums and other public forms with interested participants of state-public interaction;

- partnership, which is implemented through specially created groups of experts who provide consultations on relevant issues of public interest.

Public opinion has its own structural and operational features. It can be considered:

a) as features of the process of its expression (language, communication and joint management);

b) as a fully formed result of the communication process - a set of words, framed in accessible and understandable language constructions (expression of judgment), as well as quantitative and qualitative characteristics, confirming the degree of support for such opinions and judgments by the community.

The formation of public opinion occurs alternately in the following stages: analysis of a set of source material for the formation of beliefs, mood, assessment of importance, interests, education and knowledge, imaginary and real image of a person who can be a carrier of public opinion (I); assessment of the activities of the subjects of public opinion formation, leaders of public opinion among various segments and strata of the population (II); use of qualified structures (organizations) and other tools of formation, responsible for the formation of public opinion through the use of information and communication techniques, technologies and media sources (III); introduction of technologies in order to identify public opinion, in particular, the use of questionnaires, polls, interviews; focusing public attention on the research object (IV); integration of formulas of public opinion (judgment, which is specifically expressed) in consciousness as an element of technology of consciousness formation $(\mathrm{V})$; final reinforcement of a certain form of public opinion in the form of a statement of opinion, presentation of facts, coverage of expert opinion, demonstration of entities that support this opinion (VI).

At the same time, among the requirements for communication interaction, it is mandatory to take into account the specific features of the communication area, namely: the structure of production branches, territorial directions of priority development, provision of resources, infrastructural specifics of the economy and the possibility of providing conditions for its development, regional demographic, migratory features, etc. Thus, communicative interaction is considered as a complex system of methodologically consistent, provided with methodological and organizational and technical procedures in the framework of the individual components of social mechanisms, interconnected by one goal: obtaining reliable data on the phenomenon (process), which is investigated for the possibility of their use in the future to improve the effectiveness of communication between the government and civil society institutions. Therefore, we believe that the interaction 
of public communications is closely related to the concept of "communication practice", because mutual communication takes place only during the last.

Changes in the daily communicative practice of today's person, our contemporary, are characterized by numerous contradictions. Free access to a huge array of information data expands the potential for creative search and individual development. Global communication networks catalyze the formation of contacts between persons and individuals. However, habitual connections are gradually lost or broken, the number of direct human interactions with other members of the community decreases, the volume of nameless (anonymous) communication often increases, official communication is typically performed via telecommunications and electronic technologies, in the process of which a person seems to lose gender, age, voice, national and other important features of the social individual. As a result, the skills of traditional communication are lost, which require the individual to work on themselves, attention, mental effort, tolerance, understanding, etc. As a result of the rapid spread of new technologies at the present stage of civilization, the Internet and the Internet community have become a common and integral part of everyday life. Cyberspace is a continuation of real everyday life, complemented by new and updated features, various additional or ancillary services, characterized by accessibility, speed, simplicity and ease of use, and the possibilities of virtual communication in these conditions are almost limitless [8].

The concept of communicative rationality is used as a basis in the methodological approach to solving the vast majority of current and at the same time global international issues. The concept of communicative rationality is considered to be a theoretical construction, the basic purpose of which is to develop theoretical knowledge and practical skills based on the characteristics of rationality, mutual coherence (consensus) and understanding. Within the concept, communication is interpreted in a new way - not only as a means of spreading and disseminating information, but also as a way of communication and interaction of people in the social sphere through productive, constructive dialogue [9].

Currently, the efficiency and quality of management centers around ensuring the openness and transparency of the system of public authority, in the proper regulatory and legal consolidation of communication interaction of all subjects involved. Communication interaction as a universal management and control system aims to achieve management goals through social, communication, governance management of the audience, and along with receiving specific answers from such an audience through verbal, ideological and (or) executive reactions.

Communicative relations between the society and the government contribute to the formation of a constructive dialogue on a permanent basis, which aims to legitimately ensure the existing order and ensure its stability. The communicative policy of the state has been developing for a long time according to outdated norms since gaining the status of independence. Direct contact between the state authority and the citizen took place under the conditions of informing about the decision taken. The authorities were not very interested in the feedback from the society. The gradual development of democratic values and social transformations with the 
transition of public authorities to the principles of openness, transparency and accountability have catalyzed the transformation in the system of relations between the government and the public. The direction of implementation of European norms, declared by the state authorities, envisages the transformation of the sphere of relations between the state and the society, connected with the establishment of public relations, public dialogue, partnerships between state authorities and public citizenship.

Modern technologies of information communication in modern conditions become a significant attribute in the activities of government agencies; they perform a number of important functions. The use of these technologies in the process of building relationships with civil society institutions and the public is of particular importance for the current stage of development of the society. However, provided they are applied on the basis of approaches, the so-called "new public service", and the provisions of the theory of political networks, which are the most consistent with the requirements of modernity. These technologies contribute to an increase in the authority and trust towards the authorities, the growth of civil society activity, the reasonability of the managerial decisions taken, an increase in the effectiveness of the adopted social-economic decisions, and as a consequence, a qualitative increase in the standard of living of the society members. Simultaneously, the increase of efficiency and achieved effectiveness in the activity of power structures can be achieved due to more active involvement of community structures in the implementation of the set goals, chosen strategies, and, as a consequence, the solution of state administration issues.

Along with the issues of partnership, there are many parallel and similar methods for assessing and modeling the relations of public administration authorities with a significant number of other subjects of the current government. Thus, there is an obvious feature that implies participation of all members of society in the work of state governing bodies, the involvement of possible performers in the development of decisions that are significant for the society. However, the partnership does not rule out the need for the existence of its own authority in a particular area and professional activities in its management. Moreover, the coordination of selfgovernment with possible external influence is invariably important, because the conscious and reasonable position of the subjects of government, according to sociological grounds, is in the process of permanent internalization and, optimally, should be consistent with the laws of sustainable development of the society as a whole [10].

Such a partnership helps structured social networks with subjects of the communication process of different ownership and belonging work in a designated direction; it equalizes for each of the participants the degree and possibility of using common, that is, significant resources to protect the informal system of possible "allies" and like-minded people. Such a scheme is mutually beneficial and suitable in a competitive market, and should have its own adaptive means and resources for the sphere of administrative and political relations and communications. It should be noted that, under certain circumstances, they are formed, undergo differentiation; 
thus, they acquire their own specificity in one or another sector of contacts of new communications. In particular, such long-known form, which is identified by the term "social partnership", has received additional features. This term is used in the vast majority of such cases, if the need is to denote the constructive interaction of several sectors of the modern civil society (in our example - three): the government, the business community and the sector of non-governmental society. Participants of each of these parties have, according to the law of equal opportunities, resource opportunities for decision-making and corporate participation in creation of a construction of the society. The long lasting stratification of the civil society, inertia in the processes of reforming the social and communication sphere are the main consequences of the lack of mutual understanding and mutually beneficial cooperation for the parties in the existing sectors [11].

The functioning of constructive belonging in the interaction of the abovementioned three structures of the public community is hindered by the predominant influence of the factor of personal interest over the factors of community interests, which leads to the destruction of communication links, frustration and distrust in the prospects of change for the better and the situation itself, and the existing communication relationship. Insufficient or inadequate awareness of the structural components of one sector about potential opportunities and problems of others, in the vast majority of cases causes a decrease in the resources of national development. An increase in the effectiveness of partnership is hampered by the closed nature of decision-making mechanisms and the distribution of available resources in the sectors of state institutions, the selfish nature of entrepreneurial activity, infantilism and often lack of professionalism in the activities of public institutions and the civil society in general.

The strategic goal in the formation of mechanisms for the implementation of communication projects in building mutual relations with communities of citizens centers around achieving equality of the parties in partnership with the public, doing business in order to maximize the aspirations and interests of all partners and participants.

Communications in the process of functioning of public authorities play a very important and significant role in making management decisions, which, in turn, have an impact on the level and quality of life of citizens. The degree of effectiveness of such decisions will depend on many factors, including the understanding of the reasons and the level of approval and support of the public community of the chosen methods that will be used in solving specific problems or tasks. The implementation of any development projects and programs is problematic if there is no clear understanding of the end results of the decision, as well as whether the balance of interests of all interested parties is met. That is why currently the opinion of citizens is an important tool for influencing the activities of government and determining the vector of development of a country that positions itself as a legal and democratic one.

The analysis of communication interaction as a functional means of building communication space in the sphere of public administration gives grounds to 
emphasize that the communication space of relations between individuals of the community becomes a complex structure, which is characterized by various connections. It is characterized by the following properties and features that generally characterize the system, namely: the integrity of space (a measure of communication equilibrium), structure, volume, degree of intensity and complexity of the relationship of the components), autonomy, that is, homogeneity in terms of functions of the constituent components of the structure (placement of each constituent component in the overall system of the communication process, the number of possible options for application, suitable for use by the subjects of communication in the choice of the necessary methods and means of transmission of information appeals, and ultimately to achieve the goal of mutual communication). In the communication space, the volume, forms and types of information are always necessarily subjectively perceived and have varying degrees of subjective relevance, forasmuch as each participant in the communication process explanates the interpretation of the message of a particular communicator, joins in a dialogue with him on the basis of his own communication knowledge and skills, as well as understanding and perception of the situation of a particular communication.

The development of modern society requires the creation of new forms of cooperation and mutual understanding; respectively, it requires new forms of communication, which will be characterized by even greater efficiency, openness, transparency, effectiveness and quality. The presence of these features can provide a type of communication, the participants of which are equal and active, able not just to establish communication channels, which allow transfering information quickly in both directions, and to create an effective communication platform for resultative and mutually beneficial communication of the subjects involved in communication process.

Experts assess the information openness of public authorities as insufficient, and the practice of partnership and dialogue between the government and civil sectors is significantly limited nowadays $[12$, p. 46]. Therefore, within the modern conditions, the formation of civil society requires the introduction of new forms and methods of interaction between the state and its citizens, improving existing technologies, increasing the transparency of all activities of state institutions.

According to most modern researchers' viewpoints, the degree of efficiency of the public administration system depends on the optimization of communicative interaction between state authorities, the public and self-governing structures (institutions of local self-government). This becomes possible due to the construction of not only an effective communication policy, but also a single communicative space, which is implemented on the basis of the principle of partnership, the implementation of which assumes full public confidence in state authorities. When reporting to the public, the state authorities should be held accountable for their actions and decisions. This form of interaction is one of the effective tools of collective governance, which, in turn, ensures the strengthening of democracy, because new forms of communication between the state and the society create the 
preconditions for the development of civil society institutions and organizations, promote democratization [13, p. 94].

Formation of a new paradigm of state governance is possible through the prism of communicative management, because this concept is aimed at the most effective solution of issues at the state level. The new paradigm of state administration involves the implementation of research at three levels, namely: a description of the features and properties of state governance, systematization of cognitive approaches, the basic applied areas and their concentration. Communication management is based on the essence, content and forms of feedback [14].

The object of communicative management is a set of information flows, and the subject - the search for the best ways to manage these flows, which creates a favorable environment for governance. The condition for establishing the communicative partnership, bilateral dialogue between the government and the public is the organizational and legal capacity of civil society institutions to articulate social interests, their promotion and protection, and the success of such a dialogue depends on the joint actions of state authorities and associations of citizens and their willingness to cooperate, as state associations have a real impact on public policy, embodying the full range of opinions generated in civil society. The influence of civil society on the decision-making process is carried not only at the national level, but also at the global and international level, as international institutions are also involved in the dialogue [5].

Discussion. According to the results of the study of structural features, functions and models of communication interaction in the field of state administration, it has been revealed that communicative interaction in the context of government declares a number of internal and external functional features, which in aggregate often reflect the specific properties of such a subsystem, its response to changes in the internal state and the external environment and are mutually correlated with the systemic functions of state governance. The generally accepted model of formation of communication interaction contains target (requirements for competitiveness in activity), meaningful (informational, activity emotional and perceptual) components. In terms of content, the basic basis of the described model includes three levels (stages) of public joint activities that arise during the communication process, namely: subject as a product for another participant (it has nothing in common in the nature of activity and existence); joint communication (in the form of interaction, cooperation, which is based on the basics of personal, mutual and joint responsibility between its participants); joint activity (collective activity, conscious public).

Based on the analysis of communicative interaction as a functional means of building a communicative space in the field of public administration, it has been found that the communicative area of relations between individuals is a complex formation, which is characterized by various connections. It is characterized by the following system characteristics: complete integrity (the measure that characterizes the communicative balance), structure (the volume and the intensity, the complexity of the relationships between system components), autonomy or functional 
homogeneity of the structure components (the location of each of the components in the system of the communication process, the variable number that can be used and applied by the subjects of communication in choosing ways and means of transmitting and disseminating information to achieve the goal of communication).

The study of the role and importance of communication dialogue in public administration and its structural elements gives grounds to argue that the mechanism of dialogue between state authorities and civil society is an important factor in creating a democratic state; it ensures significant effectiveness of management decisions, their appropriate perception by community members and the formation of a system of law in the society based on the value definition of human and civil rights and freedoms, protection of their legitimate interests.

In particular, it should be emphasized that the mechanism for optimizing interaction in communications in the field of public administration determines that activities, based on partnership, are an important factor that can significantly stimulate the development of social and economic spheres of the state, as well as cultural values and the attractiveness of the territory in the eyes of investors and residents. The result of establishing a communication policy is the formation of an integrated community in the society, the development of civil society, the introduction of a positive image of local authorities, based on trust and responsibility to the community.

Conclusion. In the course of studying the mechanisms of communicative influence of public opinion on the optimization of communicative interaction in the sphere of state administration, it has been found that the formation and development of communication relations in the field of public administration as a process is complex and multifaceted, which aims to ensure: constant informative service of the system and activity of public power in the state; arrangement and establishing communication with "clients within the management system" - civil servants (that is, officials) of state administration; communication interaction with "clients outside the system" - citizens (community, population and structures of civil society institutions). Communication interaction is an important prerequisite for the effective development of a democratic society based on constant dialogue. Only ordered, properly established communication interaction will make it possible to fulfill the whole range of tasks of the state's communication policy. The state should make every effort as soon as possible to provide every possible assistance and create the necessary, technical, organizational, legal and other conditions, taking into account the economy, for the implementation of a two-way full symmetrical exchange of appropriate information between the authorities and citizens in the implementation of the constitutional right of the latter to truthfulness and publicity. In this context, we consider it advisable to use innovative communication forms and technologies, the installation and adjustment of mutual relations in the society with the public, the proper development of public relations in compliance with the general communication policy on the part of the state, aiming to establish or restore public confidence in state authorities, to promote effective and productive interaction with all segments of the population. 
Author contributions. The authors contributed equally. Disclosure statement. The authors do not have any conflict of interest.

\section{References.}

1. Azhazha, М. А.(2015), Человеческий капитал: теоретические основы и механизмы развития [Human capital: theoretical foundations and development mechanisms], Problems of spatial of socioeconomic systems: economics, education, medicine [Monograph]. Opole: The Academy of Management and Administration in Opole. P.63 - 69. [Poland]

2. Campbell, A., Converse, P. E., Miller. W. E., Stokes, D. E. ( 2013), The American Voter. 2nd ed. Chicago,. $407 \mathrm{p}$.

3. Vysotska, O. Ye. (2007), Virtualna realnist ta postratsionalna komunikatsiia v konteksti stanovlennia suspilstva postmodernu [Virtual reality and post-rational communication in the context of the formation of postmodern society], Humanitarnyi chasopys, № 4, P. 5-11. [Ukraine]

4. Horovyi, V. (2010), Sotsialni informatsiini komunikatsii, yikh napovnennia i resurs [Social information communications, their content and resource]. Kiev. 360 p. [Ukraine]

5. Code of best practices for public participation in the decision-making process CONF/PLE(2009)CODE1. (2009), Conference of International Non-Governmental Organizations of the Council of Europe 1.10.2009, retrieved from: $\mathrm{http} / / \mathrm{www}$. coe.int/t/ngo/Source/Code_Russian_final.pdf.

6. Rudovska, S. (2016), Models of public-policy making cycle: role and place of public consultation. Jurnalul juridic national: teorie şi practică. Issue 3 (19), pp. 50-54. [Moldova, Ukraine]

7. Romanenko, Ye. O. (2014), Modeli komunikatyvnoi polityky derzhavy ta instrumentalne zabezpechennia vzaiemodii orhaniv derzhavnoi vlady ta hromadskosti [Models of communication policy of the state and instrumental support of interaction of public authorities and the public]. Democratic governance. № 14, retrieved from: http://nbuv. gov.ua/UJRN/DeVr_2014_14_11. [Ukraine]

8. Matveichuk, L. O. (2016), Elektronne uriaduvannia: pravovyi aspekt [E-government: legal aspect]. Investments: practice and experience. № 9, pp. 85-88. [Ukraine]

9. Tverdokhliebov, Ye. O. (2014), Teoretychni zasady doslidzhennia komunikatyvnoi vzaiemodii $v$ publichnomu upravlinni [Theoretical bases of research of communicative interaction in public management]. Theory and practice of public administration. № 2, pp. 82-91. [Ukraine]

10. Stepanov, V. N. (2003) Provokatyvnyi dyskurs sotsyalno-polytycheskoi kommunykatsyy [Provocative discourse of social and political communication]. St. Petersburg. 263 p. [Russia]

11.Lubchenkov, Yu. N. K voprosu o kommunykatyvnykh mekhanyzmakh sotsyalnoho partnerstva [On the issue of communicative mechanisms of social partnership]. (2004). Proceedings from: Social processes and social relations in modern Russia: abstracts of speeches at the IV Int. social congr, In 2 t. Moscow, t.1, pp. 245-247. [Russia]

12.Titz, Susan, Cohen, Laurie, Masson, Jill. (2008), Yazyk orhanyzatsyi. Ynterpretatsyia sobыtyi y sozdanye tsennostei [The language of organizations. Interpreting Events and Creating Values]. Kharkiv, Publishing House of the Humanitarian Center, 324 p. [Russia]

13. Arkhypova, Ye. O., Dmytrenko, N. O. (2016), Efektyvna komunikatsiia mizh orhanamy derzhavnoi vlady ta hromadskistiu yak umova rozvytku demokratychnoho suspilstva [Effective communication between public authorities and the public as a condition for the development of a democratic society]. Investments: practice and dosvid. № 1. pp. 92-96. [Ukraine]

14.Rivers, W., Christians, C., Schramm, W. (2017), Responsibility in Mass Communication. N.Y., 723 p.

15.Akimov, O. (2020). Public administration: robustness and the systemic genesis aspect. Public Administration and Law Review, (1), 46-54. https://doi.org/10.36690/2674-5216-2020-1-46-54

Received: September 25, 2020 Approved: October 20, 2020 